\title{
Mondkapjesdraagplicht
}

\section{Is er überhaupt een medisch gegronde reden tot vrijstelling?}

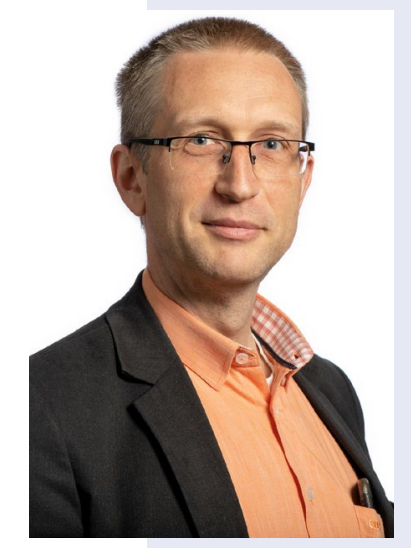

Dr. Edelhart Y. Kempeneers, Medisch directeur, Externe Dienst voor Preventie en Bescherming op het werk Attentia, België

\section{Edelhart Kempeneers}

Nederland heeft sinds 1 december 2020 de verplichting tot het dragen van een mondkapje in publieke binnenruimtes. Een dergelijke verplichting werd in België al in juli 2020 ingevoerd, bijvoorbeeld in het openbaar vervoer en in de horeca. Ondertussen is dat uitgebreid naar alle omstandigheden waarin mensen onvoldoende afstand kunnen houden. Op deze draagplicht zijn wel in beide gevallen uitzonderingen voorzien als mensen om gegronde medische redenen geen mondkapje kunnen dragen. Ik ben van mening dat er nauwelijks gegronde medische redenen zijn voor ontheffing van de mondkapjesplicht!

In maart 2020 is het alom paniek in België. De cijfers van bevestigde besmettingen lopen alarmerend op, de ziekenhuizen lopen vol, en een strategische voorraad van mondkapjes blijkt enkele jaren terug vernietigd en niet vervangen.

Terecht wordt het tekort aan mondkapjes aan de schandpaal genageld, want dit leidt zeker in de woonzorgcentra tot vele onnodige zware zieken en doden. De Belgische overheid kondigt vervolgens een complete lockdown af, en haastig wordt gezocht naar hoogstnodige voorraden van mondkapjes, in de eerste plaats voor de zorgverleners en bij uitbreiding voor alle burgers.

$\mathrm{Na}$ zes weken lockdown, begin mei 2020, worden de niet-essentiële ondernemingen in België voorzichtig heropend, mits bijkomende voorzorgsmaatregelen in acht worden genomen. De bevolking krijgt, eindelijk, de verzuchte mondkapjes. Via de apotheek kan elke burger gratis een wasbaar en dus herbruikbaar mondkapje ophalen.

En twee weken later willen diezelfde Belgische burgers die mondkapjes niet meer hebben.

Buschauffeurs van het openbaar vervoer klagen over de hinder die de mondkapjes met zich meebrengen. Zijn die nu echt, écht nodig?

De burgers wordt 'sterk aanbevolen' om mondkapjes te dragen tijdens hun winkelbezoek. 'Sterk aanbevolen' wordt eerder geïnterpreteerd als 'kijk eerst of er veel andere mensen zijn die het dragen, en indien niet, steek het onding dan snel terug in je zak voordat men je vreemd aanstaart'.

Uiteindelijk voert de overheid een mondkapjesplicht in, eerst in het openbaar vervoer en in de horeca, vervolgens ook tijdens het winkelbezoek, en ook op de werkvloer wanneer men onvoldoende afstand kan houden.

Behalve als er een gegronde medische reden is, dan volstaat een gelaatsscherm, zo geeft een verhaast opgesteld Ministerieel Besluit begin juli 2020 mee: Zelfs indien ze niet volledig gelijkwaardig zijn in termen van bescherming, gelaatsschermen mogen worden gebruikt, bij wijze van medische uitzondering, wanneer het dragen van een mondmasker problematisch of onmogelijk is. En zelfs dat gelaatsscherm is niet meer nodig volgens een nieuw Besluit in augustus 2020: De personen die in de onmogelijkheid zijn een mondmasker, een alternatief in stof of een gelaatsscherm te dragen omwille van een beperking, gestaafd door middel van een medisch attest, moeten niet voldoen aan de bepalingen van dit besluit die deze verplichting voorzien. En vervolgens druppelen bij de werkgevers de medische attesten binnen van werknemers die dergelijke vrijstellingen vragen.

De werkgever is volgens de Belgische Welzijnswet verplicht om de gezondheid en veiligheid van zijn werknemers zoveel mogelijk te verzekeren en hen een veilige werkplek te bieden. In uitvoering hiervan heeft die werkgever een risicoanalyse opgesteld volgens de richtlijnen die de overheid heeft opgesteld in haar Generieke Gids om de verspreiding van COVID-19 op het werk tegen te gaan. Hierin is een volgorde van prioriteiten bepaald volgens de preventiehiërarchie, waarbij de werkgever in eerste instantie collectieve maatregelen moet nemen, gevolgd door individuele bescherming. Is telewerk geen optie? Dan is een maximale naleving van de regels van social distancing aan de orde. Is dat niet mogelijk? Dan kan de werkgever het dragen van een mondkapje opleggen om de veiligheid van de werknemers te garanderen. 


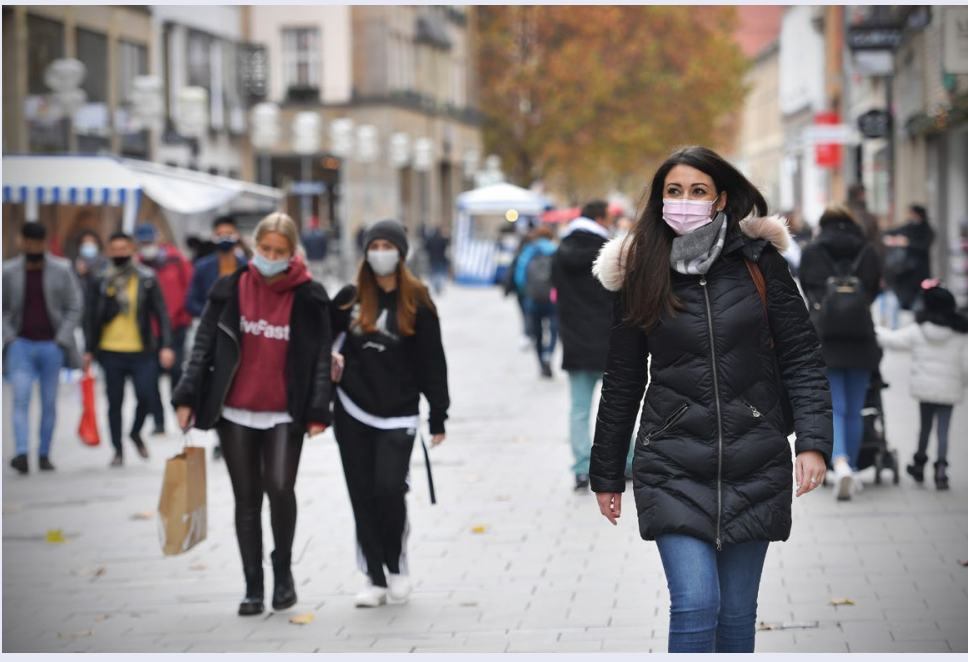

Een werknemer die weigert deze instructies op te volgen, kan om dringende reden ontslagen worden. Wat bijvoorbeeld ook gebeurt in één onderneming, een beslissing die op 8 juli 2020 door een Arbeidsrechtbank wordt bestendigd.

Maar wat moet of kan de werkgever doen wanneer de werknemer zwaait met een medisch attest van diens behandelend arts?

Hier komt de arbeidsarts op het toneel.

Die was trouwens al actief achter de coulissen, bij het helpen opstellen van de risicoanalyse op de werkvloer. Maar bij een vraag tot individuele vrijstelling van een werknemer, moet de werkgever die doorsturen naar de arbeidsarts, die dan oordeelt of de vraag al dan niet gegrond is. Indien wel gegrond, dan kan die arbeidsarts adviseren de werknemer van de mondkapjesplicht te ontheffen en oordelen of de werknemer mag verder werken op de huidige werkpost, dan wel aangepast of ander werk moet krijgen.

Maar wanneer is een dergelijke vraag überhaupt gegrond? Om welke reden zou iemand 'in de onmogelijkheid' zijn om een mondkapje (of gelaatsscherm) te dragen omwille van een beperking?

Om al direct een mythe de wereld uit te helpen: mondkapjes leiden niet tot een daling van het zuurstofgehalte in het bloed. Men verliest nogal eens uit het oog dat mondkapjes al decennia lang gebruikt worden. Chirurgen dragen zulke mondkapjes dag in dag uit, uren aan een stuk, en het is toch niet dat je bij hen hersenschade ${ }^{\star} .$. Oké, slecht voorbeeld.

In ieder geval, ik heb van tal van pneumologen de bevestiging gekregen dat zij voor geen enkele van hun luchtwegpatiënten een dergelijke vrijstelling zouden voorschrijven. Niet voor astmatici, niet voor COPD-lijders, niet voor mucoviscidosepatiënten. Integendeel zelfs. De verhoogde ademweerstand is niet invaliderend, en na een korte gewenningsperiode merk je haast niet meer dat je een mondkapje op hebt.

Wellicht zitten mondkapjes niet altijd even comfortabel, maar daar is aan te verhelpen. Aften in de mond bijvoorbeeld zijn een gevolg van mondmaskers die te strak zitten. Dus een kleine aanpassing verhelpt hieraan.

'Ontbrekende oren' zou een argument kunnen zijn, maar voor twintig cent vind je al een earsaver die hiervoor een oplossing biedt. So, no luck, Vincent.

Trigeminusneuralgie is een valabele reden, aangebracht door een neuroloog in de Facebookgroep COVID-19 voor artsen waar ik de vraag heb geponeerd. Maar deze invaliderende aandoening is zo zeldzaam dat hier niet de stortvloed van attestjes voor binnenkomen.

Bepaalde ernstiger vormen van autisme of mentale beperkingen zijn uiteraard ook gegronde medische redenen. Maar als arbeidsarts kom ik dergelijke gevallen op de werkvloer niet zo vaak tegen, behalve dan misschien in kaderfuncties ${ }^{*} .$.

De vaakst aangehaalde reden tot het geven van vrijstellingen is nog om psychische redenen. Patiënten die beginnen te hyperventileren bij het dragen van een mondkapje, en denken dat ze beginnen te stikken. Maar ook hier is de consensus dat deze mensen meer gebaat zouden zijn met ademhalingsoefeningen dan een vrijstelling. En een echte larvofobie ${ }^{\star \star}$ zal ongetwijfeld in de medische vakliteratuur beschreven staan, maar zal niet zo frequent voorkomen in de algemene beroepsbevolking.

Ik kan dus stellen dat quasi alle getuigschriftjes met vragen tot vrijstelling van dragen van een mondkapje in feite welwillendheidsattesten zijn. Hier kunnen wij als arbeidsartsen echter niet op ingaan, want we moeten de veiligheid en gezondheid helpen waarborgen van alle werknemers, én het publiek waarmee zij vanuit hun functie in contact komen. Uiteraard mogen we het individuele welzijn van de werknemer niet uit het oog verliezen, die vaak oprecht meent dat het dragen van een mondkapje een ondraaglijke opdracht is. Maar tot dusver heb ik, via persoonlijke uitleg en in één geval individuele begeleiding van de werknemer door een arbeidspsycholoog, elke vraag tot vrijstelling kunnen afwentelen en de werknemer kunnen overtuigen tot het uitproberen van dit preventiehulpmiddel.

* I'm kidding!

** Larvofobie: Larva = Latijn voor masker. Dus larvofobie $=$ angst voor maskers 